\title{
Systematic Contributions to Taxa Dorycnium hirsutum (Fabaceae) in Turkey
}

\author{
Yusuf Ziya KOCABAŞ1, ${ }^{*}$, Ahmet İLÇİM ${ }^{2}$
}

${ }^{1}$ Department of Medical and Aromatic Plants, Türkoğlu Vocational Schools, Kahramanmaraş Sütçü İmam University, Türkoğlu, Kahramanmaraş, TURKEY ${ }^{2}$ Department of Biology, Science and Arts Faculty, Mustafa Kemal University, Antakya, TURKEY

ORCID ID: Yusuf Ziya KOCABAŞ: https:// orcid.org/0000-0003-2831-8910; Ahmet İLÇİM: https://orcid.org/0000-0001-8169-2472

\begin{abstract}
\begin{tabular}{llll}
\hline Received: 30.03 .2020 & Accepted: 18.05 .2020 & Published online: 21.05 .2020 & Issue published: 29.06 .2020
\end{tabular}
Abstract: Some interesting plant samples collected from Samandağ district of Hatay province were examined and it was determined that these specimens belong to Dorycnium hirsutum var. syriacum. Its status in the Flora of Turkey is mentioned as suspicious. In this study, it is stated that the Dorycnium hirsutum species should be divided into two distinct varieties as Dorycnium hirsutum var. hirsutum and Dorycnium hirsutum var. syriacum to investigate the morphological, taxonomic and palynological features of these taxa. Diagnostic characters and detailed descriptions of taxa and species identification key are given and IUCN categories are proposed.
\end{abstract}

Keywords: Dorycnium, Fabaceae, taxonomy, Turkey.

\section{Türkiye'deki Dorycnium hirsutum (Fabaceae) Taksonlarına Sistematik Katkılar}

Öz: Yapılan arazi incelemeleri sırasında Hatay-Samandağ bölgesinde toplanan bazı bitki örneklerinin, Türkiye florasında varlığından şüpheli olarak bahsedilen Dorycnium hirsutum var. syriacum olduğu tespit edilmiştir. Bu çalışmada Dorycnium hirsutum türünün Dorycnium hirsutum var. hirsutum ve Dorycnium hirsutum var. syriacum olmak üzere iki varyeteye ayrılması gerektiği belirtilmiş, taksonların morfolojik, taksonomik ve palinolojik özellikleri araştırılmıştır. Taksonlara ait ayırt edici karakterler, ayrıntılı betimlemeler ile tür teşhis anahtarı verilmiş ve IUCN kategorileri önerilmiştir.

Anahtar kelimeler: Dorycnium, Fabaceae, taksonomi, Türkiye.

\section{Introduction}

Dorycnium genus is included in the Loteae family of the Papilionoideae subfamily in the Leguminosae family (Brockwell \& Neal-Smith, 1966; Duke, 1981; Sheppard \& Douglas, 1986). 13 species of the genus Dorycnium have been described, spreading throughout the world (Allen \& Allen, 1981; Slavik, 1995; Davies, Howieson, Yates, \& Lane, 2005). There are 9 taxa belonging to the genus in Turkey, 4 of which are endemic (Davis, 1970; Vural, 1983; Güner, Özhatay, Ekim, \& Başer, 2000). In his work titled Flora of Turkey Davis (1970) mentioned some plant specimens about this genus which are distributed in Hatay and where the indumentum is sparse and the fruit length is equal to the calyx. Moreover, he stated that detailed investigations should be carried out with more samples. During the revision of the genus Dorycnium, which is distributed in Turkey, some interesting plant samples collected from Samandağ district of Hatay province were examined and it was determined that these specimens belong to $D$. hirsutum (L.) Ser. var. syriacum (Boiss.) Boiss. (Kocabaş, 2014). This taxon is distributed in Syria but its sample was collected from Samandağ, Hatay. This taxon is clearly separated from $D$. hirsutum (L.) Ser. var. hirsutum by the fact that the body and part of the calyx are pink in color, the sparse indumentum and the fruit stature are almost equal to that of the calyx (Boissier, 1872; Davis, 1970). This study aims to contribute to the genus Dorycnium, to provide the taxonomic $D$. hirsutum species in Turkey, and to specify that D. hirsutum var. hirsutum and D. hirsutum var. syriacum should be represented by two taxa. In the study, the morphological characters of the taxa are indicated by supporting photographs; their detailed descriptions, distributions and habitats and the species identification key are arranged and the IUCN category was proposed.

\section{Material and Methods}

The plant samples evaluated in this study were collected and turned into herbarium material (herbarium number style: YZK-Xxx) by the field studies carried out in 2012 in Turkey. These specimens are used for morphological and palynological studies. Detailed taxonomic studies on the samples were conducted according to the descriptions of different sources (Boissier, 1872; Davis, 1970; Güner et al., 2000) and they were compared with type specimens and with others at different herbaria (ANK, GAZI, HUB, ISTE E, BR and G, [The herbarium samples examined are marked with the abbreviation "!"]). For the morphological studies and descriptions, at least ten specimens were investigated. Palynological investigations were made by both light and scanning electron microscope (SEM). At the light microscope studies, the pollen slides were prepared according to the Wodehouse technique (Wodehouse, 1935). The pollen grains were covered with gold and photographs were taken with SEM. Palynological terminology follows Erdtman (1960) and Punt, Hoen, Blackmore, Nilsson and Le Thomas (2007). The seeds were investigated and photographed under SEM like the pollen. According to the data obtained, the ecology of the taxa and the category are also proposed (IUCN, 2011). The plant

\footnotetext{
*Corresponding author: kocabasyzeksu.edu.tr
} 
samples studied are preserved in Kahramanmaraş Sütçü İmam University, Türkoğlu Vocational Schools herbarium.

\section{Results and Discussion}

As a result, two taxa examined were collected from natural habitats in Turkey. Comparative and detailed taxonomic examinations were carried out on the samples. Dorycnium hirsutum in Turkey should be represented with the two taxa as D. hirsutum var. hirsutum and D. hirsutum var. syriacum.

\subsection{Dorycnium hirsutum (L.) Ser. var. hirsutum (Fig. 1,2,3)}

Perennial herb or small sub-shrub. Stems 30-65 cm long, green with pinkish and densely pubescent. The upper part of the body is more hairy than the lower part. Leaves with a short rachis, $1-4 \mathrm{~mm}$; leaflets $8-20 \times 3-10 \mathrm{~mm}$, oblongobovate, densely pubescent, mucronat. Internodes 1.5-5.7 $\mathrm{cm}$. Inflorescence 6-11-flowered, peduncles $1.5-4 \mathrm{~cm}$. Pedicels shorter than calyx-tube, 1-2 mm; calyx 6-12 mm, densely pilose, calyx teeth lanceolate-subulate somewhat longer than tube, 3.5-6.5 mm. Calyx-tube straight and pinkish, 3-5.5 mm. Flowers 9-16 mm, white or pink; banner 15-16 mm, wing 10-11 mm not united, carina $9 \mathrm{~mm}$, carina ends sometimes purplish red. Ovary $4-5 \mathrm{~mm}$, stylus $3 \mathrm{~mm}$. Legume 6-10 x 2-4.5 mm, ovat-oblong, beak $4 \mathrm{~mm}$, sometimes purplish red above, valves not contorting at maturity. Seeds 2-7, surface flat-reticulate, oblong, $1.05 \mathrm{x}$ $1.63 \mathrm{~mm}$. Pollen grains prolate, $\mathrm{P} \times \mathrm{E}=28.72 \times 20.87 \mu \mathrm{m}$.

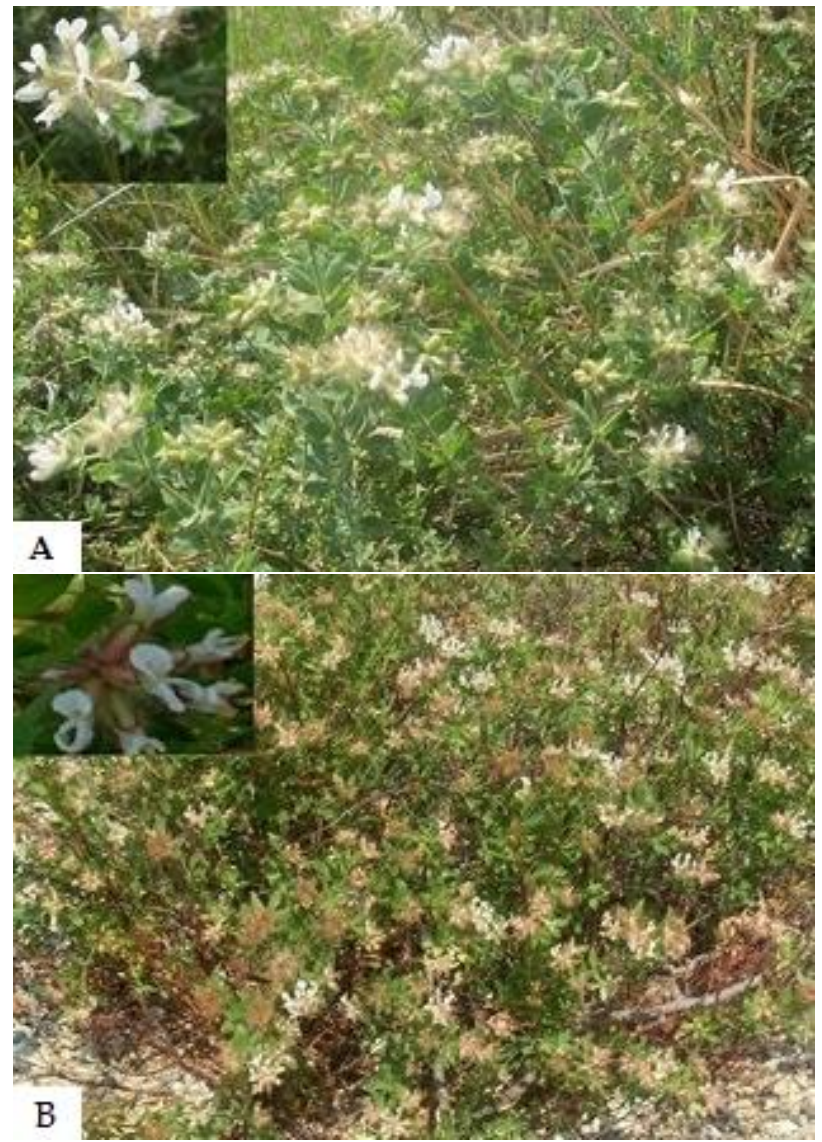

Figure 1. D. hirsutum var. hirsutum (A), D. hirsutum var. syriacum (B)

Examined specimens: A1 Çanakkale: Erenköy, 10.5.1856, Kırk (E)!; Gelibolu, 90 m, 16.5.1923, Kett 27 (K)!; Gelibolu, Ulgardere, 28.5.1923, Irigoldby 261 (K)!. A2 İstanbul:
Büyükada, 29.05.1931, H.Demiriz 3294 (ANK)!; Şile 12,5. km, 100 m, 19.04.2004, Y.Sezer 226. B1 İzmir: Gaziemir, 15.12.1967, Peşmen 2001 (EGE, ISTF)!; Efes, 90 m, 23.5.1962, Dudley \& Davis 34923 (E, ISTF, K)!; Kemalpaşa, 3.6.1966, Alava \& Bocquet 4982 (E)!; Selçuk, 37 94'648' K, 27 29'30" D, 9 m, 10.05.2011, B.Özüdoğru 2935 HUB)!. B2 Manisa: Avdal, 140 m, 18.05.2002, D.Sarl; Manisa mountain 400 m, 9.5.2005, C.Durmuşkahya; Beydere, 19.05.2007, Y.Metin. C1 Aydın: Efes to Söke, 90 m, Dudley (Davis 34923) (E)!. C2 Muğla: Marmaris, 250 m, 27.06.1997, H.Şağban 1841 (GAZI)!; Marmaris to Muğla 3. km, 150 m, Dudley (Davis 35488) (E)! C3 Antalya: Adrasan, 27.05.1950, Heilbornn \& Attila. C5 Mersin: Kuzucubelen road, Demiriz 965 (ISTF)!; Adana: Karataş, 1 m, 19.04.1998, H.Şağban 2058 (GAZI)!; Kadirli to Andirın, 431 m, K:37 25'091', D:36 09'598', 05.05.2013, YZK 952 (KSUH). C6 Osmaniye: Gavur mountain, 18.05.1956, Hub.-Morath 47 (ANK)!; Hatay: İskenderun, Nergislik, Amanos mountain, $700 \mathrm{~m}$, 08.06.1967, Y.Akman 46 (ANK)!; Batıayaz to Samandağ 2. km, 270 m, K:36 08'056", D:35 58'316"', 06.05.2012, YZK 885 (KSUH); Between to Erikli and Batıayaz, $464 \mathrm{~m}, \mathrm{~K}: 36$ 09'344", D:35 59'201"' 06.05.2012, YZK 886 (KSUH); Arsuz, 164 m, K:36 19'475", D:35 48'436", 06.05.2012, YZK 887 (KSUH); Batıayaz to Yoğunoluk road seperation, $291 \mathrm{~m}$, K:36 08'149", D:35 58'260', 06.05.2012, YZK 888 (KSUH); Arsuz output, roas sides, 293 m, K:36 23'228', D:35 51'412", 06.05.2012, YZK 889 (KSUH); Arsuz to Çevlik, 1 m, K:36 14'127", D:35 49'432" , 06.05.2012, YZK 890 (KSUH) (Fig. 2).

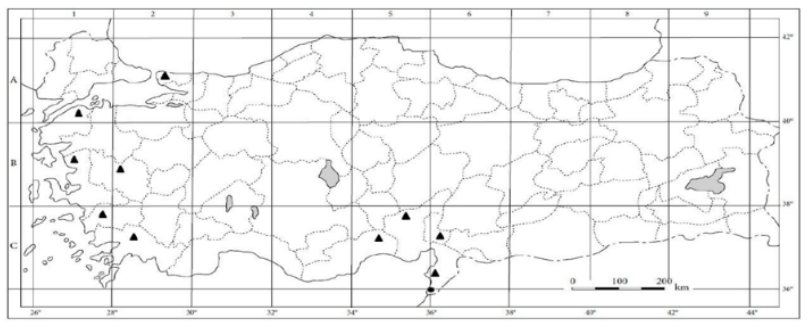

Figure 2. Geographical distribution of D. hirsutum var. hirsutum $(\boldsymbol{\Delta})$ and D. hirsutum var. syriacum $(\bullet)$ in Turkey.

Flowering and Fruiting Time: April-June.

Distributions and Habitats: Calcareous and steep slopes, dry hills, scrubs and Pinus brutia forests (Fig. 1).

Conservation Status: This taxon has a very wide distribution with different natural habitats in Turkey. We recommend the protection status of this taxon as Least Concern (LC), (IUCN, 2011) (Fig. 2).

Pollen Morphology: Pollen grains are of radial symmetry and isopolar. Polar axis (P), $28.72 \mu \mathrm{m}(27.78-29.93 \mu \mathrm{m})$ equatorial axis (E), $20.87 \mu \mathrm{m}(19.2-21.87 \mu \mathrm{m})$. Pollen shape tricolporate - prolate (P/E:1.37). Colpuses are slender-long (Clg), $20.70 \mu \mathrm{m}$ (19.1-21.57 $\mu \mathrm{m})$; (Clt), $0.76 \mu \mathrm{m}$ (0.71-0.86 $\mu \mathrm{m})$, their borders are prominent, their types are tapering. Pores spheroid (Plg:4.70 $\mu \mathrm{m}$, Plt:4.55 $\mu \mathrm{m}, \mathrm{Plg} /$ Plt:1.03). The ornamentation is tectate - faveolate and slightly rugulate. Exine: $1.10 \mu \mathrm{m}$ (Table 1 and Fig. 3).

Seed Characteristics: Seeds; $1.05 \times 1.63 \mathrm{~mm}$ in size, oblong, reniform shape, surface ornamentation is reticulate and the upper part of the seed, which is close to the hilum, is quite broadly flat and has deep folds (Table 1 and Fig. 3). 


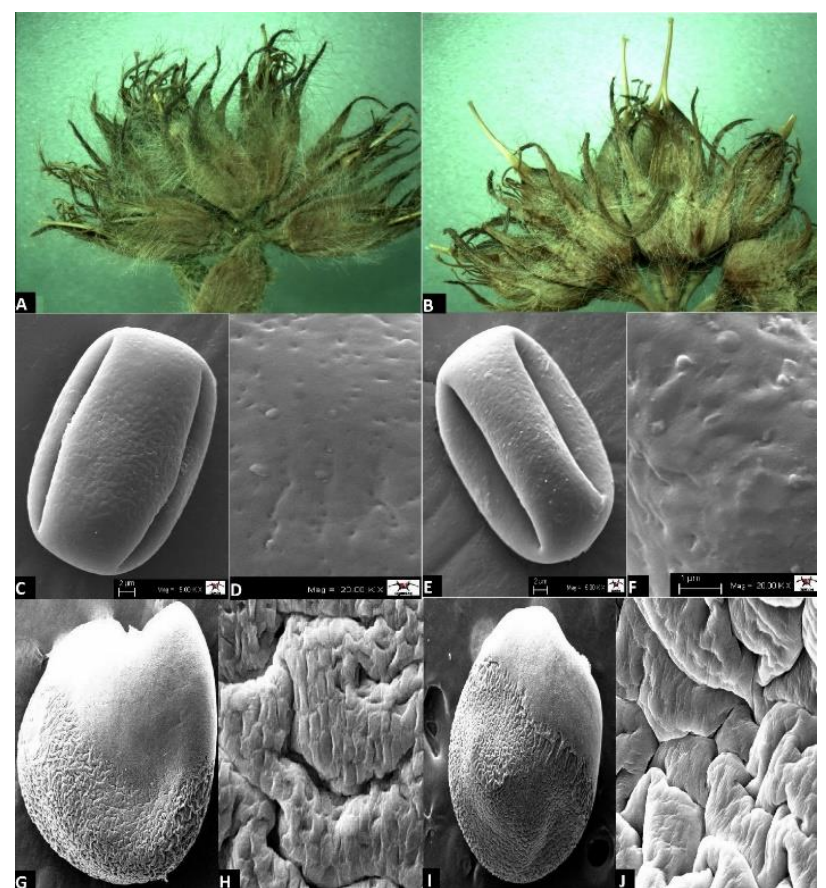

Figure 3. D. hirsutum var. hirsutum, A.Calyx, C. Pollen, D. Pollen ornamentation, G. Seed, H. Seed ornamentation; D. hirsutum var. syriacum, B. Calyx, E. Pollen, F. Pollen ornamentation, I. Seed, J. Seed ornamentation.

Table 1. Comparison of selected characters of Dorycnium hirsutum var. hirsutum (A) and D. hirsutum var. syriacum (B).

\begin{tabular}{lcc}
\hline Characters & A & B \\
Indumentum & densely pubescent with & sparsely pubescent or \\
patent & $1-4 \mathrm{~mm}$ & glabrescent \\
Rachis & $8-20 \times 3-10 \mathrm{~mm}$ & $2-2.5 \mathrm{~mm}$ \\
Leaflets & $1.5-5.7 \mathrm{~cm}$ & $16-20 \times 5-9 \mathrm{~mm}$ \\
Internodes & $9-16 \mathrm{~mm}$ & $1-4 \mathrm{~cm}$ \\
Flowers & $6-10 \times 2-4.5 \mathrm{~mm}$ & $6-13 \mathrm{~mm}$ \\
Legume & $28.72 \times 20.87 \mu \mathrm{m}$, & $6-9 \times 4-4.3 \mathrm{~mm}$ \\
Pollen (PxE) & tricolporate-prolate & $31.52 \times 21.33 \mu \mathrm{m}$, \\
& tricolporate-prolate \\
Seed & 2-7,1.05 1.37 ) & $(\mathrm{P} / \mathrm{E}: 1.47)$ \\
& oblong-reniform & 2-6, $1.50 \times 1.33 \mathrm{~mm}$, \\
& & oblong-reniform \\
\hline
\end{tabular}

3.2. Dorycnium hirsutum (L.) Ser. var. syriacum (Boiss.) Boiss., Fl. Or. 2:161 (1872) (Fig. 1,2,3)

Perennial herb or small sub-shrub. Stems 30-65 cm long, green with pinkish and sparsely pubescent with patent hairs or glabrescent. Lower parts of the stems almost naked and the upper part sparsely hairy. Leaves with a short rachis, 2-2.5 mm; leaflets 16-20 x 5-9 mm, oblongobovate, sparsely hairy to almost naked, mucronat, internodes 1-4 cm. Inflorescence 4-11-flowered, peduncles 0.7-3.5 cm. Pedicels shorter than calyx-tube, $1-1.2 \mathrm{~mm}$; calyx 6-9 mm, sparsely pilose, calyx teeth lanceolatesubulate somewhat longer than tube, 3-5 mm. Calyx-tube straight and pinkish, 3-4 mm. Flowers 6-13 mm, white or pink; banner 12-13 $\mathrm{mm}$, wing 10-11 $\mathrm{mm}$ not united, carina $11 \mathrm{~mm}$, carina ends sometimes purplish red. Ovary 4-5 $\mathrm{mm}$, stylus $3 \mathrm{~mm}$. Legume 6-9 x 4-4.3 mm, ovat-oblong, beak 4-4.5 mm, sometimes purplish red above, valves not contorting at maturity. Seeds 2-6, surface flat-reticulate, oblong, $1.50 \times 1.33 \mathrm{~mm}$. Pollen grains prolate, $\mathrm{P} \times \mathrm{E}=31.52$ $x 21.33 \mu \mathrm{m}$.

Examined Specimens: C6 Hatay: Antakya, Süveydiye, 05.07.1846, Boiss.; Between to Arsuz, Samandağ, $4 . \mathrm{km}$. roadsides, $10 \mathrm{~m}, \mathrm{~K}: 36$ 23'543"', D:35 51'596', YZK 883
(KSUH), (Fig. 2).

Flowering and Fruiting Time: April-June.

Distributions and Habitats: Seaside, roadside, dry hills, macchie (Fig. 1).

Conservation Status: This taxon is distributed only in Hatay (Samandağ) district in Turkey. We recommend the protection status of this taxon, which is represented by 2030 individuals in a very narrow area near the sea in Turkey, as critical (B2a), (IUCN, 2011) (Fig. 2).

Pollen Morphology: Pollen grains are of radial symmetry and isopolar. Polar axis (P), $31.52 \mu \mathrm{m}(31.4-42.1 \mu \mathrm{m})$ equatorial axis (E), 21.33 $\mu \mathrm{m}(21.29-21.69 \mu \mathrm{m})$. Pollen shape tricolporate - prolate (P/E:1.47). Colpuses are slender-long (Clg), $21.83 \mu \mathrm{m}(21.80-21.95 \mu \mathrm{m})$; (Clt), $0.72 \mu \mathrm{m}$ (0.71-0.75 $\mu \mathrm{m})$, their borders are prominent, their types are tapering.

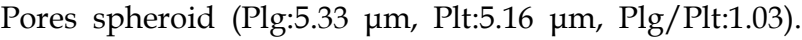
The ornamentation is tectate - faveolate and slightly rugulate. Exine: 0,98 $\mu \mathrm{m}$ (Table 1 and Fig. 3).

Seed Characteristics: Seeds; $1.50 \times 1.33 \mathrm{~mm}$ in size, oblong, round shape, surface ornamentation is reticulate and the upper part of the seed, which is close to the hilum, is quite broadly flat and has deep folds (Table 1 and Fig. 3).

D. hirsutum var. syriacum is clearly separated from its closest relative $D$. hirsutum var. hirsutum by the fact that the body and part of the calyx are pink in color, the fruit length is almost equal to the calyx with its sparse indumentum. Accordingly, the diagnostic key we propose to distinguish these two taxa is as follows:

1. Plant clearly densely pubescent, flowers 9-16 mm, calyx 6-12 mm longer than fruit........... var. hirsutum

2. Plant sparsely indumentum, flowers $6-13 \mathrm{~mm}$, calyx 6$9 \mathrm{~mm}$ equalling the fruit.................. var. syriacum

D. hirsutum var. syriacum, is distributed in Syria (Boissier, 1872; Post, 1933). Its distribution was recorded not so far from Turkey and its status in the Flora of Turkey is mentioned as suspicious (Davis, 1970). However, it is determined based on the revised study that the genus Dorycnium is also distributed in Turkey (Kocabaş, 2014). It is also identified by the anatomical differences between taxa (Kocabaş \& İlçim, 2016). For these taxa any protection status is not specified (Ekim et al., 2000).

\section{Conclusion}

According to the results of this study, it is determined that the species $D$. hirsutum in Turkey should be represented with the two taxa as $D$. hirsutum var. hirsutum and $D$. hirsutum var. syriacum. These two taxa examined were collected from their natural habitats and their morphological and taxonomic features were investigated. Detailed descriptions of taxa and species identification key are given. D. hirsutum var. hirsutum taxon has a densely pubescent and a longer calyx than its fruit, while the $D$. hirsutum var. syriacum has a sparse indumentum and a calyx of the same size as the fruit. D. hirsutum var. hirsutum is proposed Least Concern (LC) as it spreads in very wide and different habitats, while D. hirsutum var. syriacum is proposed as Critically (B2a) conservation status because it is known from only one locality in Turkey. 
Acknowledgements: The authors thank to the Scientific Investigation Projects Coordinate Office of the University of Kahramanmaras Sutcu Imam (Project no: 2013/4-22 D) for the financial support. This study is a part of the Ph.D.thesis titled "The Taxonomic Revision of Dorycnium (Fabaceae) Genus Growing in Turkey" by Yusuf Ziya KOCABAŞ.

\section{References}

Allen, O.N., \& Allen, E.K. (1981). The Leguminosae. A source book of characteristics, uses and nodulation. Wisconsin, University of Wisconsin Press, 812 pp. https://doi.org/10.1007/BF02858721

Boissier, E. (1872). Flora Orientalis. Vol. 2. Basel-Geneva, 1172 pp.

Brockwell, J., \& Neal-Smith, C.A. (1966). Effective nodulation of hairy canary clover, Dorycnium hirsutum (L.) Ser. In DC. Australia. CSIRO Division of Plant Industry Field Station Record, 5(1), 9-15.

Davis, P.H. (ed.), (1970). Flora of Turkey and East the Aegean Islands. In H. Demiriz (Eds.), Vol. 3. Edinburgh, Edinburg University Press, 512-518.

Davies, S.R., Howieson J.G., Yates R.J., Lane P.A. (2005). Selection and Evaluation of Root Nodule Bacteria For Dorycnium spp. Australian Journal of Experimental Agriculture, (2-3), 241-246. http://dx.doi.org/10.1071/ea03127

Duke, J.A. (1981). Handbook of Legumes of World Economic Importance. London, Plenum Press, 345 pp. http:/ / dx.doi.org/10.1002/star.19820341011.

Ekim, T., Koyuncu, M., Vural, M., Duman, H., Aytaç, Z., \& Adigüzel, N. (2000). Red Data Book of Turkish Plants (Pteridophyta and Spermatophyta). Turkish Association for the Conservation of Nature, Ankara, Van Yüzüncüyıl University Press, 246 pp.

Erdtman, G. (1960). The acetolysis method, a revised description. Svensk Botanisk Tidskrift, 54, 561-564.

Güner, A., Özhatay, N., Ekim, T., \& Başer, K.H.C. (2000). Flora of Turkey and the East Aegean Islands. Vol. 11, Edinburgh, Edinburgh University Press., 656 pp.

International Union for Conservation of Nature and Natural Resources (IUCN) (2011). IUCN Red List Categories and Criteria: Version 3.1. IUCN Species Survival Commission, Gland, Switzerland.

Kocabaş, Y.Z., \& İlçim, A. (2016). Anatomical Features of Dorycnium Miller (Fabaceae) Species Growing in Turkey. Karaelmas Science and Engineering Journal, 6(1), 83-89.

Post, G.E. (1933). Flora of Syria, Palestine and Sinai, From Taurus to Ras Muhammad and From Mediterranean Sea to The Syrian Desert. (2 nd. ed., revised by J.E.Dinsmore), Vol. 1-2, (pp. 247248), Beirut, American Press., 919 pp.

Punt, W., Hoen, P.P., Blackmore, S., Nilsson, S., \& Le Thomas, A. (2007). Glossary of pollen and spore terminology. Review of Palaeobotany and Palynology, 143, 1-81. http://dx.doi.org/10.1016/j.revpalbo.2006.06.008

Sheppard, J.S., \& Douglas, G.B. (1986). Management and uses of Dorycnium spp., In: Plant materials handbook for soil conservation, Volume 2. Introduced plants, Technical note no. H6, (pp. 282-286). Wellington, New Zealand, 299 pp.

Slavik, B. (1995). A Plant-Geographical Study of The Genus Dorycnium Mill. (Fabaceae) in The Czech Republic. FoliaGeobotanic and Phytotaxonomica, 30(3), 291-314. http://dx.doi.org/10.1007/bf02803712.

Student, Kocabaş, Y.Z. (2014). The Taxonomic Revision of Dorycnium (Fabaceae) Genus Growing in Turkey. Graduate School of Natural and Applied Sciences, (PhD Thesis), Kahramanmaraş Sütçü Imam University, Kahramanmaraş, Turkey.

Wodehouse, R.P. (1935). Pollen Grains. New York, USA, 578 pp.
Vural, M. (1983). New Taxa and Records from Turkey (Dorycnium sanguineum Vural). Notes from the Royal Botanic Garden, Edinburgh, 41(1), 67-69. 